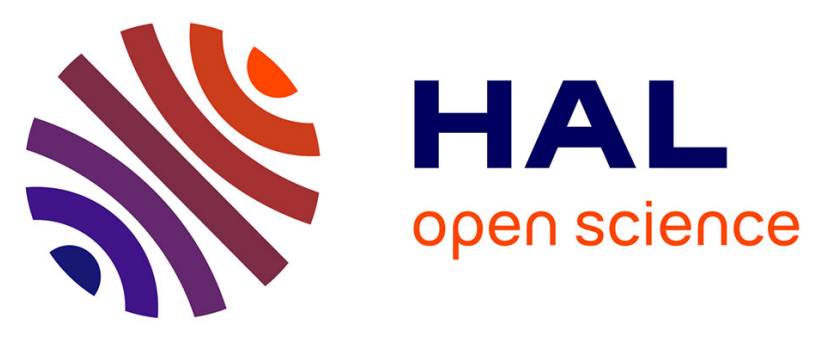

\title{
An inducible surface presentation system improves cellular immunity against human papillomavirus type 16 E7 antigen in mice after nasal administration with recombinant lactococci.
}

Luis L. Bermudez Humaran, Naima Cortes-Perez, Yves Le Loir, Juan M

Alcocer-González, Reyes S Tamez-Guerra, Roberto Montes de Oca-Luna,

Philippe P. Langella

\section{To cite this version:}

Luis L. Bermudez Humaran, Naima Cortes-Perez, Yves Le Loir, Juan M Alcocer-González, Reyes S Tamez-Guerra, et al.. An inducible surface presentation system improves cellular immunity against human papillomavirus type $16 \mathrm{E} 7$ antigen in mice after nasal administration with recombinant lactococci.. Journal of Medical Microbiology, 2004, 53, pp.427-433. 10.1099/jmm.0.05472-0 . hal-02683034

\section{HAL Id: hal-02683034 \\ https://hal.inrae.fr/hal-02683034}

Submitted on 1 Jun 2020

HAL is a multi-disciplinary open access archive for the deposit and dissemination of scientific research documents, whether they are published or not. The documents may come from teaching and research institutions in France or abroad, or from public or private research centers.
L'archive ouverte pluridisciplinaire HAL, est destinée au dépôt et à la diffusion de documents scientifiques de niveau recherche, publiés ou non, émanant des établissements d'enseignement et de recherche français ou étrangers, des laboratoires publics ou privés. 


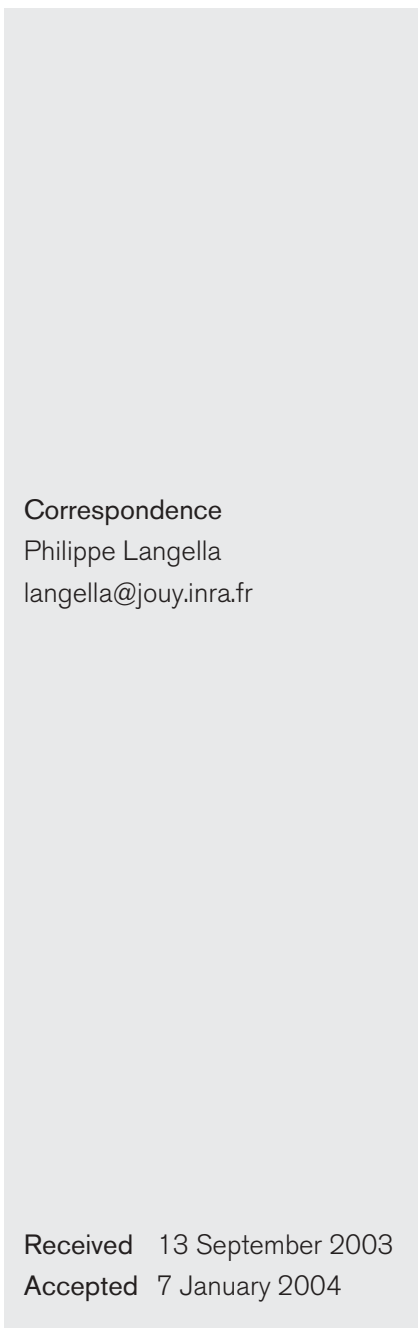

\title{
An inducible surface presentation system improves cellular immunity against human papillomavirus type $16 \mathrm{E} 7$ antigen in mice after nasal administration with recombinant lactococci
}

\author{
Luis G. Bermúdez-Humarán, ${ }^{1,2}+$ Naima G. Cortes-Perez, ${ }^{1,2}+$ Yves Le Loir, ${ }^{2}$ \\ Juan M. Alcocer-González, ${ }^{1}$ Reyes S. Tamez-Guerra, ${ }^{1}$ \\ Roberto Montes de Oca-Luna ${ }^{1}$ and Philippe Langella ${ }^{2}$ \\ ${ }^{1}$ Laboratorio de Inmunología y Virología, Facultad de Ciencias Biológicas. Universidad Autónoma de \\ Nuevo León, San Nicolás de los Garza, N.L., Mexico \\ ${ }^{2}$ Unité de Recherches Laitières et de Génétique Appliquée, INRA, Domaine de Vilvert, 78352 \\ Jouy-en-Josas cedex, France
}

\begin{abstract}
Human papillomavirus type 16 (HPV-16) is the major causative agent of cervical cancer. To date, vaccine strategies against HPV-16 are based on the ability of the E7 oncoprotein to elicit an immune response against this virus. In this study, the use of an inducible or a constitutive system to produce the HPV-16 E7 protein in Lactococcus lactis, a non-pathogenic and non-invasive Gram-positive bacterium, was compared. The highest E7 production was obtained with the inducible system. When mice were immunized intranasally with recombinant lactococci expressing either inducible or constitutive E7, an antigen-specific cellular response (i.e. secretion of IL2 and IFN- $\gamma$ cytokines) was evoked and was substantially higher in mice receiving L. lactis expressing E7 with the inducible system. As bacterial antigen location may influence the immune response, recombinant $L$. lactis strains that produced E7 in three cellular locations, intracellular, secreted or cell-wall-anchored were evaluated. The highest immune response was elicited by administration of $L$. lactis producing an inducible cell-wall-anchored form of E7 protein. These promising results represent a step towards the development of a new, safe mucosal vector to treat HPV-related cervical cancer.
\end{abstract}

\section{INTRODUCTION}

Epidemiological data have clearly shown that human papillomavirus type 16 (HPV-16) infection is the main aetiological factor for cervical cancer $(\mathrm{CxCa})$ (Furumoto \& Irahara, 2002). Worldwide, $\sim 400000$ women die annually from CxCa (Parkin et al., 1999). A prophylactic and/or therapeutic vaccine against this virus is thus a priority to prevent or to treat, respectively, $\mathrm{CxCa}$. A prophylactic vaccine based on highly purified virus-like particles has recently been successfully used in trials in women, with a significant reduction observed in the incidence of both HPV-16 infection and related $\mathrm{CxCa}$ (Koutsky et al., 2002). However, such vaccines could probably not be used therapeutically in alreadyinfected patients because the virion capsid proteins are not detected in $\mathrm{CxCa}$. The HPV-16 E7 protein, constitutively produced in cervical carcinomas, is required for the trans-

tThese authors contributed equally to this work.

Abbreviations: $\mathrm{CxCa}$, cervical cancer; HPV-16, human papillomavirus type 16; LAB, lactic acid bacteria. formation process (Baker et al., 1987; Bedell et al., 1987; Dyson et al., 1989; Tanaka et al., 1989) and is considered a good antigen candidate for the development of a therapeutic vaccine against $\mathrm{CxCa}$.

Several studies have investigated the use of bacteria as E7 antigen delivery vehicles to elicit an immune response against HPV-16. In these studies, the vectors used were attenuated strains of pathogenic bacteria such as Salmonella and Mycobacterium spp. (Londoño et al., 1996; Jabbar et al., 2000). Although these recombinant strains elicited immune responses, invasiveness of the vectors and risks of reversion to pathogenicity limit their use in vulnerable groups such as immunocompromised patients or children. There is thus a need for the development of a new generation of safe delivery vehicles.

Lactic acid bacteria (LAB) are promising candidates as safe vehicles for in vivo delivery of antigens. Compared with attenuated bacterial vectors, LAB are non-pathogenic and non-invasive Gram-positive organisms and 'generally recognized as safe' (GRAS). Furthermore, some LAB species 
reportedly exert probiotic effects in humans and some are widely used in the food industry. Our team previously reported E7 production in Lactococcus lactis, the model LAB (Bermúdez-Humarán et al., 2002, 2003a,b; Cortes-Perez et al., 2003). Vaccination through mucosal routes using L. lactis constitutes an easy and low-cost administration method. In addition, as L. lactis is a non-commensal and transient bacterium in the digestive tract (Drouault et al., 1999; Geoffroy et al., 2000), the risk of eliciting a tolerance response to the antigen delivered is diminished compared with persistent bacteria.

Although high production of heterologous proteins in L. lactis has been obtained using constitutive promoters (de Vos, 1999), continuous high-level production of a protein could lead to intracellular accumulation or degradation in the cytoplasm, which could, in some cases, be deleterious to the cell. Thus, in this study, we evaluated the use of a constitutive system versus an inducible system [nisin inducible system, NICE (de Ruyter et al., 1996; Kuipers et al., 1998)] to produce the HPV-16 E7 protein in L. lactis. NICE is a versatile system where gene expression can be up-regulated more than 1000-fold (de Ruyter et al., 1996). Furthermore, as immunogenicity may depend on the antigen location, the immune response was evaluated for three recombinant L. lactis strains targeting E7 antigen to the cytoplasm, the medium or to the cell-wall.

The highest production of E7 was obtained with the inducible system. When mice were immunized with $L$. lactis targeting E7 to different cellular locations, an E7-specific cellular response (i.e. secretion of IL 2 and IFN- $\gamma$ cytokines) was evoked and was higher in mice receiving $L$. lactis producing an inducible cell-wall-anchored form of E7. These strains are thus good candidates for the therapy and prevention of HPV-related CxCa.

\section{METHODS}

Bacterial strains, plasmids and DNA manipulations. Plasmid constructs used in this study allowing the inducible production of HPV-16 E7 protein in the cytoplasm (pCYT:E7) or secreted into the culture medium (pSEC:E7) in L. lactis: NZ(pCYT:E7) and NZ(pSEC:E7) have been described previously (Bermúdez-Humarán et al., 2002). L. lactis was grown in M17 (Difco) supplemented with $1 \%$ glucose (GM17) at $30{ }^{\circ} \mathrm{C}$ without shaking. Plasmid constructions were established in L. lactis as described previously (Langella et al., 1993) and maintained by the addition of $10 \mu \mathrm{g}$ chloramphenicol $\mathrm{ml}^{-1}$ or $5 \mu \mathrm{g}$ erythromycin $\mathrm{ml}^{-1}$. DNA manipulations were performed using standard methods essentially as described by Sambrook et al. (1989).

Plasmid construction to express E7 protein in L. lactis constitutively. To express E7 protein in L. lactis under the transcriptional control of a constitutive promoter, the following DNA manipulations were performed: briefly, an E7:trpA cassette was purified from pCYT:E7 digested with BamHI-Klenow/SpeI and cloned into a pIL backbone purified from pVE5546 digested with NruI/SpeI (Dieye et al., 2001), resulting in pILCYT : E7. In this plasmid, the E7 gene is under the control of $\mathrm{P}_{59}$, a lactococcal constitutive promoter (van der Vossen et al., 1987) commonly used for heterologous gene expression in L. lactis (Piard et al., 1997; Chatel et al., 2001). This plasmid, designed for constitutive cytoplasmic E7 production, was introduced into L. lactis MG1363 (Gasson, 1983) resulting in MG(pILCYT:E7).

Plasmid constructions to express a cell-wall-anchored E7 protein in L. lactis with an inducible system. Recently, we have described a pILCWA:E7 vector to display E7 protein at the cell wall of L. lactis (Cortes-Perez et al., 2003). However, pILCWA:E7 is a derivative of pVE5547, a large theta-replicating plasmid that is difficult to manipulate (Dieye et al., 2001). An $\mathrm{SP}_{\mathrm{Usp}}-\mathrm{E} 7-\mathrm{CWA}_{\mathrm{M} 6}$ cassette was transferred from pILCWA:E7 into a pGK derivative, a smaller Escherichia coliGram-positive shuttle vector that is easier to manipulate (Kok et al., 1984; Bermúdez-Humarán et al., 2002, 2003c). Briefly, the $\mathrm{SP}_{\mathrm{Usp}}$-E7$\mathrm{CWA}_{\mathrm{M} 6}$ cassette was purified from pILCWA:E7 digested with BglII/ SpeI and cloned into the pGK backbone purified from pSEC:E7 digested with BglII/SpeI. The resulting plasmid, pCWA:E7, was introduced into L. lactis NZ9000 resulting in NZ(pCWA: E7).

Immunoblotting. Fresh medium was inoculated 1:50 (v/v) with an overnight culture and incubated at $30{ }^{\circ} \mathrm{C}$ without shaking. To induce the nisin-inducible promoter, strains were grown until $\mathrm{OD}_{600} \sim 0 \cdot 6$, followed by induction with $10 \mathrm{ng}$ nisin $\mathrm{ml}^{-1}$ (Sigma) for $1 \mathrm{~h}$. For the $L$. lactis strain expressing E7 protein under the control of $\mathrm{P}_{59}$ [MG(pILCYT : E7)], cultures were harvested at $\mathrm{OD}_{600} \sim 0 \cdot 8$, which corresponds to an $\mathrm{OD}_{600}$ similar to that reached after $1 \mathrm{~h}$ of nisin induction for other strains. Sample preparation and immunoblotting assays were performed as described before (Bermúdez-Humarán et al., 2002, 2003a), using anti-E7 antibodies for immunodetection (HPV-16 E7; Santa Cruz Biotechnology).

Preparation of live bacterial inoculum. Bacterial cultures were prepared as described above. At $\mathrm{OD}_{600} \sim 0.8$ for both constitutive and nisin-induced strains, cell pellets were harvested by centrifugation at $3000 \mathrm{~g}$ at $4{ }^{\circ} \mathrm{C}$ and washed three times with sterile PBS. The pellets were suspended in PBS to a final concentration of $1 \times 10^{9}$ c.f.u. Plate counts were performed to check the number of c.f.u. administered and E7 production was assessed by immunodetection.

Immunizations. Groups of five C57BL/6 mice (6-8 weeks; Jackson Laboratory, Bar Harbor, ME) were immunized intranasally with $1 \times 10^{9}$ c.f.u. of each induced recombinant $L$. lactis strain (suspended in $10 \mu \mathrm{l}$ PBS; $5 \mu \mathrm{l}$ was administered with a micropipette into each nostril) on days 0,14 and 28 . Mice were partially anaesthetized by intraperitoneal injection of ketamine $(1.5 \mathrm{mg}$ for $100 \mathrm{~g}$ of weight; Cheminova de México). Control mice received identical quantities of wild-type (wt) L. lactis or PBS alone. Experiments were performed according to protocols approved by the International Animal Studies Committee.

Determination of IL2 and IFN- $\gamma$ cytokine production in splenocytes. Mice immunized with recombinant $L$. lactis strains and control mice were sacrificed on day 35. Splenocytes were separated on a FicollHypaque (Sigma) density gradient. A total of $2 \times 10^{6}$ cells $^{-1}$ in AIM$\mathrm{V}$ medium (Gibco) were plated in a 24 -well plate $(2 \mathrm{ml}$ per well), at $37{ }^{\circ} \mathrm{C}$ under $5 \% \mathrm{CO}_{2}$. Splenocyte suspensions were restimulated with $2 \mu \mathrm{g}$ of a synthetic E7 peptide (RAHYNIVTF) to determine whether in vitro restimulation induced a peptide-specific cellular response. After $24 \mathrm{~h}$, cell suspensions were filtered and supernatants were examined for the presence of IL2 and IFN- $\gamma$ cytokines by ELISA (R\&D Systems).

Statistics. Student's $t$-test was performed using the MINITAB computer software package. 


\section{RESULTS AND DISCUSSION}

\section{Evaluation of mucosal immune response in mice after intranasal administration of $L$. lactis producing E7 antigen under the transcriptional control of either a constitutive or an inducible promoter}

In the last decade, several studies have used L. lactis as an antigen delivery vehicle to develop safe, live vaccines (Robinson et al., 1997; Steidler et al., 1998; Chatel et al., 2001; Enouf et al., 2001; Bermúdez-Humarán et al., 2002; Ribeiro et al., 2002; Xin et al., 2003). In these studies, different transcriptional and translational lactococcal signals have been used to express antigens. However, no report correlates the efficacy of expression systems and gene expression control by a constitutive or an inducible promoter. To address this question, E7 production was analysed in MG(pILCYT:E7) and NZ(pCYT:E7) by immunoblot experiments using anti-E7 antibodies (Fig. 1a). In the cell fraction of NZ(pCYT:E7), one band was detected at the expected size for native E7 (19 kDa) (Bermúdez-Humarán et al., 2002). A similar band was detected in the cell fraction of MG(pILCYT: E7); however, the intensity of the E7 signal was about threefold lower than NZ(pCYT:E7). As expected, no E7 signal was detected in the supernatant samples of either strain. This result shows that, under these induction conditions, NZ(pCYT:E7) produces a larger amount of E7 than does MG(pILCYT:E7). The ability of these two strains to induce an immune response in mice was compared. Groups of five mice were immunized with MG(pILCYT:E7) or induced NZ(pCYT:E7). Seven days after the last boosting (day 35), mice were sacrificed and levels of IFN- $\gamma$ and IL2 produced by cytotoxic T lymphocytes (CTL) were measured by ELISA, in samples prepared from splenocytes restimulated in vitro with an HPV-16 E7-specific CTL epitope (RAHYNIVTF; Fig. $1 \mathrm{~b}$ and c). Splenocytes prepared from immunized mice produced levels of IL2 (Fig. 1b) and IFN- $\gamma$

Fig. 1. Evaluation of the capacity of $L$. lactis to produce $E 7$ antigen under transcriptional control of either a constitutive or an inducible promoter. (a) E7 production was analysed by Western blot of protein extracts of strains NZ(pCYT:E7) (inducible promoter) and MG(pILCYT:E7) (constitutive promoter). C, Cell lysate; S, supernatant fraction. Positions and sizes of molecular mass markers are indicated on the left. ( $b$ and $c$ ) Evaluation of immune response in mice immunized with the two recombinant $L$. lactis strains producing $E 7$ under either a constitutive or an inducible promoter. Levels of IL2 (b) and IFN- $\gamma$ (c) were assayed by ELISA following immunization of mice with $1 \times 10^{9}$ c.f.u. of different strains of L. lactis: wt, MG(pILCYT: E7) and NZ(pCYT : E7). A control placebo group of non-immunized mice was included. Values were recorded as the mean and standard deviation of five mice per treatment group. Statistically significant differences $(P<0.05)$ are denoted by an asterisk $\left(^{*}\right)$ between controls and immunized groups or by a cross ( + ) between NZ(pCYT:E7) and MG(pILCYT:E7) immunized groups. These data are representative of three separate experiments showing similar results.
(Fig. 1c) that were significantly higher than the controls (i.e. splenocytes of non-immunized mice or mice immunized with wt L. lactis). Both IL2 and IFN- $\gamma$ levels were approximately twofold higher in mice immunized with $\mathrm{NZ}(\mathrm{pCYT}: \mathrm{E7})$ than in mice immunized with MG(pILCYT:E7) (Fig. 1b and c). These results show (i) that both recombinant strains are able to induce an antigen-specific CTL response in mice and (ii) that E7 immune response is correlated to the dose of antigen delivered by recombinant lactococci. The amount of E7 delivered by NZ(pCYT:E7) induced culture was indeed approximately threefold higher

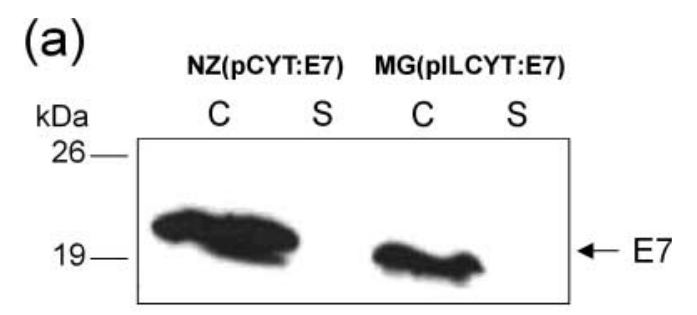

(b)

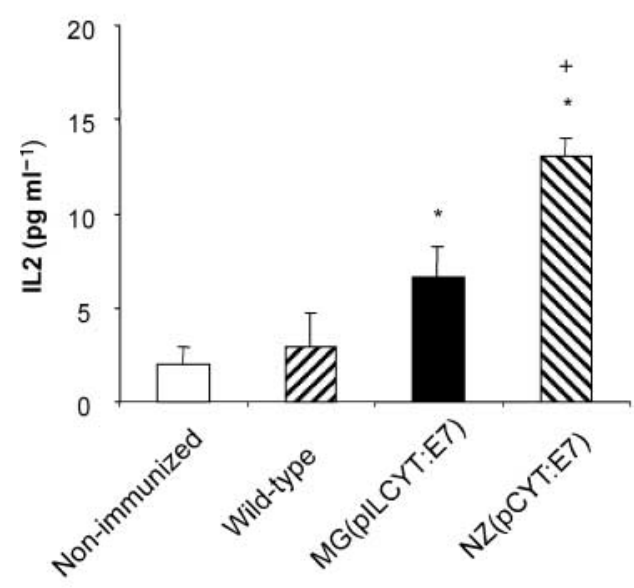

(c)

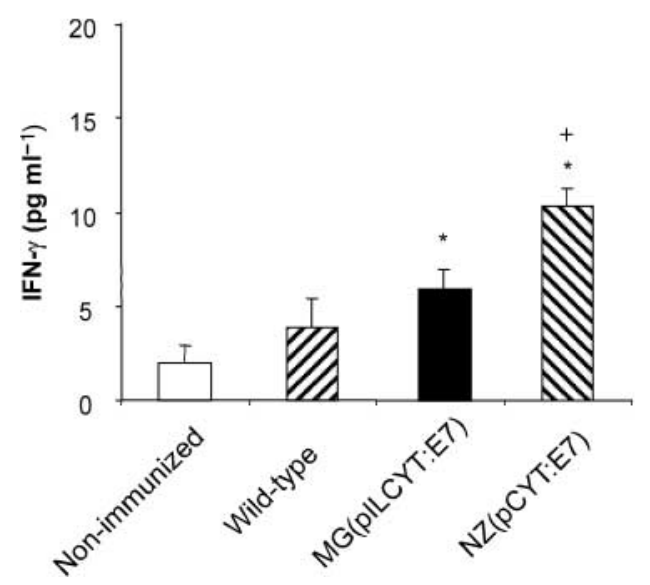


than that delivered by MG(pILCYT:E7) culture (Fig. 1a). These results led us to use inducible strains such as $\mathrm{NZ}$ (pCYT : E7) for further experiments.

\section{Comparison of immune response in mice after intranasal administration of recombinant $\boldsymbol{L}$. lactis targeting E7 to different cellular localizations}

As protein localization may influence immunogenicity (Norton et al., 1996; Reveneau et al., 2002), we analysed the immune response elicited in mice by three different strains of L. lactis producing the E7 antigen either in the cytoplasm, secreted into the external medium or cell-wallanchored, using strains NZ(pCYT:E7), NZ(pSEC:E7) and $\mathrm{NZ}$ (pCWA:E7), respectively. Our hypothesis was that an exported protein (secreted into the medium or cell-wallanchored) would have direct contact with the target (i.e. the immune system). Protein export may thus be a better strategy compared with intracellular production, which requires cellular lysis for protein delivery. Before immunizations, E7 production in the different induced cultures was analysed by Western blotting and immunodetection using anti-E7 antibodies. As previously observed in Fig. 1(a), samples of induced $\mathrm{NZ}(\mathrm{pCYT}: \mathrm{E} 7)$ cultures contained a band that corresponded to native E7 in the cell fraction (Fig. 2a).
No E7 signal was detected in the supernatant. For $\mathrm{NZ}$ (pSEC : E7), a very faint band corresponding to $\mathrm{SP}_{\mathrm{Usp}^{-}}$ E7 precursor (preE7) was observed in the cell fraction, whereas an intense band corresponding to secreted mature E7 was detected in the supernatant fraction (Fig. 2a). As previously reported (Bermúdez-Humarán et al., 2002), E7 is very efficiently secreted ( $\sim 95 \%$ of the over-expressed protein is found in the supernatant) and the yield is about three- to fivefold higher than that obtained with the intracellular form (Fig. 2a). For NZ(pCWA : E7), one major band was detected in the cell fraction at the expected size $(\sim 38 \mathrm{kDa})$ for an $\mathrm{SP}_{\mathrm{Usp}}-\mathrm{E} 7-\mathrm{CWA}_{\mathrm{M} 6}$ precursor (preCWAE7) together with two other bands of lower molecular mass corresponding to the $\mathrm{E} 7-\mathrm{CWA}_{\mathrm{M} 6}$ form, which results from the cleavage of $\mathrm{SP}_{\mathrm{Usp}}$, and the mature E7-CWA generated after processing of $\mathrm{CWA}_{\mathrm{M} 6}$ (i.e. cleavage of $\mathrm{CWA}_{\mathrm{M} 6}$ and covalent link between E7 and the cell wall). A third faint band was also detected between the preCWA-E7 and E7-CWA $\mathrm{M}_{\mathrm{M}}$ forms, which probably corresponds to an alternative cleavage product of preCWA-E7. Confirmation of E7 display at the cell surface of L. lactis was performed by immunofluorescence, essentially as described before (Fig. 2b; Cortes-Perez et al., 2003). These results showed that, even though induction levels were similar, the amount of E7 produced in NZ(pCYT : E7) was significantly (three- to fivefold) lower

\section{(a)}

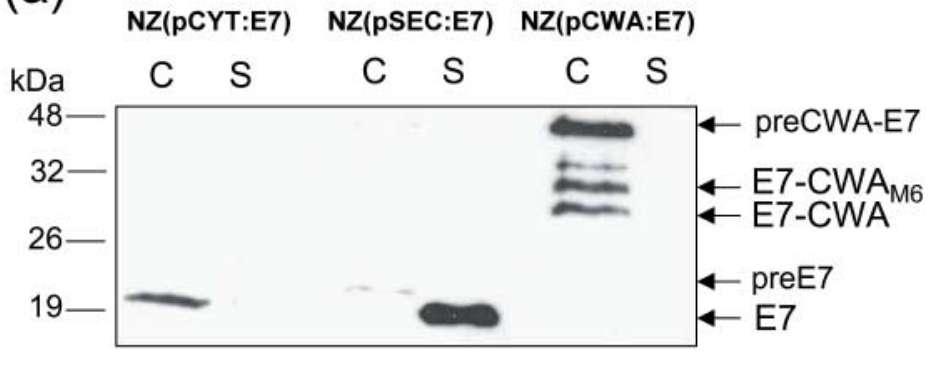

(b)
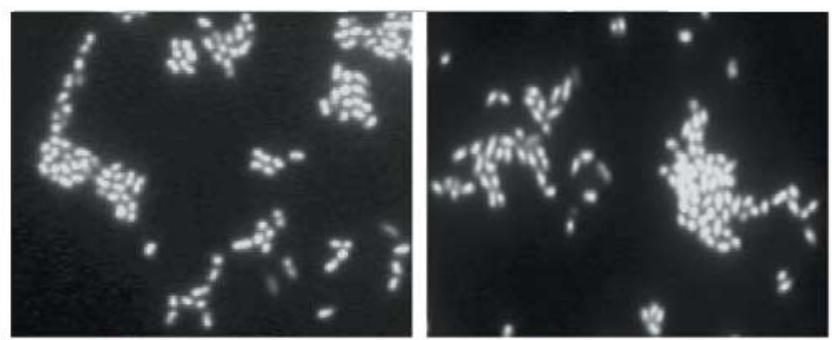

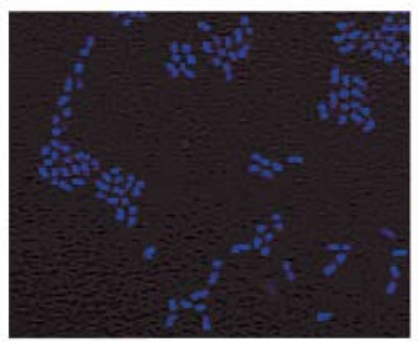

L. lactis

wt

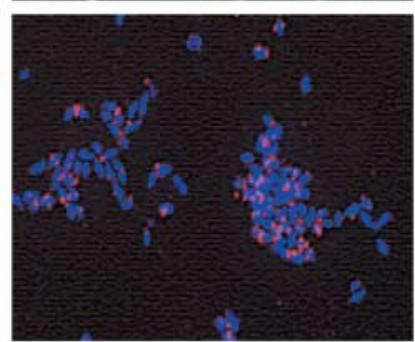

L. lactis

NZ(pCWA:E7)
Fig. 2. Analysis of recombinant L. lactis strains producing $\mathrm{E} 7$ in three different cellular localizations and detection of E7 at the cell-wall surface by immunofluorescence. (a) E7 production was analysed by Western blot of protein extracts of strains NZ(pCYT:E7) (intracellular E7 production), NZ(pSEC : E7) (secreted E7 production) or NZ(pCWA:E7) (cell-wall-anchored E7 production). C, Cell lysate; S, supernatant fraction. Positions and sizes of molecular mass markers are indicated on the left. The third faint band between preE7 and E7-CWA $\mathrm{A}_{\mathrm{M}}$ forms probably corresponds to an alternative cleavage product of preE7. (b) Recombinant NZ(pCWA : E7) or wt $L$. lactis samples were treated with specific antiE7 $\mathrm{mAbs}$ and then fluorescence-stained with goat anti-lgG conjugate Alexa Fluor 546 dye (lower panels). Corresponding non-stained microscopic fields (DAPI stained) are shown (upper panels). Magnification, $\times 1000$. 
than that of NZ(pSEC:E7) or NZ(pCWA:E7). However, in $\mathrm{NZ}$ (pCWA:E7), most of the E7 is found in a precursor (intracellular) form. The amount of E7-CWA displayed at the cell surface was similar to that produced in $\mathrm{NZ}$ (pCYT:E7), and was estimated to be $\sim 2 \mu \mathrm{g} \mathrm{m}^{-1}$ by comparison with the signals of known amounts of E7 by quantitative scanning of blots after immunodetection (Image-Quant; Bermúdez-Humarán et al., 2002).

Immunogenicity of the E7 antigen produced in the three different localizations by L. lactis strains was then tested. Groups of five mice were immunized intranasally and levels of IL2 and IFN- $\gamma$ cytokines were measured as described above. Splenocytes obtained from mice immunized with $\mathrm{NZ}$ (pCWA:E7) and restimulated in vitro produced higher cytokine levels than those obtained from mice immunized

(a)

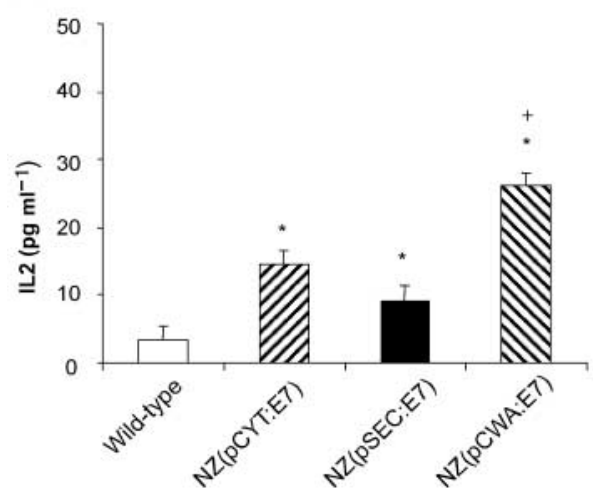

(b)

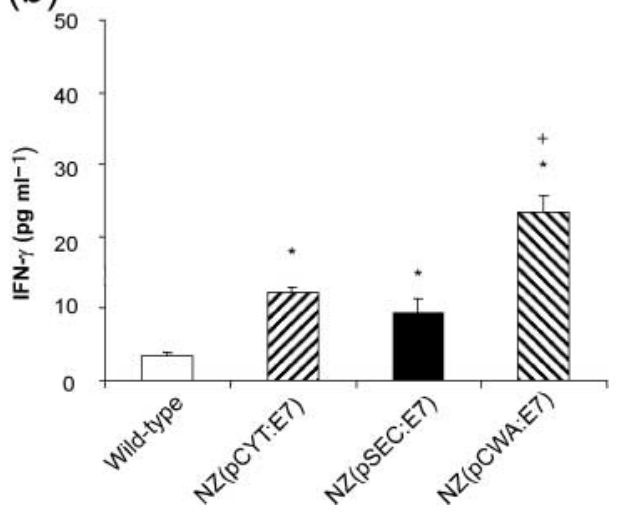

Fig. 3. Evaluation of immune response in mice immunized with the three recombinant $L$. lactis producing $E 7$ in different cellular localizations. Levels of IL2 (a) and IFN- $\gamma$ (b) cytokines were assayed by ELISA following immunization of mice with $1 \times 10^{9}$ c.f.u. of different $L$. lactis strains: wt, NZ(pCYT:E7), NZ(pSEC:E7) or NZ(pCWA : E7). Statistically significant differences $(P<0.05)$ between the wt immunized group and NZ(pCYT:E7), NZ(pSEC:E7) or NZ(pCWA:E7) immunized groups are denoted by an asterisk $\left(^{*}\right)$. Significant differences between NZ(pCYT : E7), NZ(pSEC : E7) or NZ(pCWA : E7) immunized groups are denoted by a cross (+). These data are representative of three separate experiments showing similar results. with the NZ(pCYT: E7) strain (Fig. 3a and b). As discussed above, in NZ(pCWA:E7), the amount of cell-wall-anchored E7 was estimated to be $\sim 2 \mu \mathrm{g} \mathrm{ml}^{-1}$, similar to the cytoplasmic E7 production in NZ(pCYT:E7). The higher immunogenicity of E7 delivered by NZ(pCWA : E7) could result from the cell surface display of E7 in L. lactis. This type of result has been previously reported in LAB (Norton et al., 1996; Reveneau et al., 2002), and was attributed either to a better accessibility to the immune system when the antigen is exposed at the bacterial surface or to some adjuvant properties of the LAB vector itself. Although the amounts of E7 in $\mathrm{NZ}(\mathrm{pCYT}$ : E7) and surface-exposed E7-CWA in NZ(pCWA:E7) are quite similar, the total amounts of E7 forms are much higher in NZ(pCWA:E7) than in NZ(pCYT : E7). The greater immune response obtained with NZ(pCWA : E7) could thus be due to a combination of cell surface display and a dose-dependent response (after release of the preCWA-E7 by cell lysis), as shown above. The immune response obtained with NZ(pSEC:E7) was lower than that observed in mice immunized with NZ(pCYT:E7) and NZ(pCWA : E7) (Fig. 3a and b). This result could be due to the protocol used for cell preparation prior to immunization (see above). In contrast to NZ(pCYT:E7) and $\mathrm{NZ}$ (pCWA:E7), where all the E7 forms produced are found in the cell fraction, in NZ(pSEC:E7) E7 is released into the supernatant (discarded during sample preparation) (Fig. 2a). Thus, the amounts of E7 delivered in immunization with NZ(pSEC: E7) might be very small (only trace amounts of preE7 were detected in the cell fraction) if heterologous protein production and secretion stop once nisin is removed during and after sample preparation.

We therefore checked whether $L$. lactis continues to produce E7 antigen after a nisin pulse. Production and secretion of E7 by NZ(pSEC:E7) were analysed by Western blot and immunodetection. NZ(pSEC:E7) was induced with $10 \mathrm{ng}$ nisin $\mathrm{ml}^{-1}$ for $1 \mathrm{~h}$ (nisin pulse). After the nisin pulse, cells were recovered and thoroughly washed three times with fresh culture medium (GM17) to eliminate all traces of nisin. After the last wash, the cell pellet was suspended in GM17 and growth was pursued for $6 \mathrm{~h}$ as described previously (Bermúdez-Humarán et al., 2003c). Culture samples were taken at intervals of 2, 4 and $6 \mathrm{~h}$ and analysed by Western blot and immunodetection using anti-E7 antibodies (Fig. 4). Interestingly, the quantity of E7 protein in the washed sample $4 \mathrm{~h}$ after the nisin pulse was about twofold higher than in the sample prepared from non-washed culture just after the nisin pulse (Fig. 4). Similar results were recently observed with two other heterologous proteins, the staphylococcal nuclease and the ovine IFN- $\omega$ (Bermúdez-Humarán et al., 2003c). This result could be due (i) to the toxic effect of nisin (nisin is a lactococcal bacteriocin, active on $L$. lactis strains) on NZ(pSEC: E7), since L. lactis NZ9000 strain does not possess a nisin resistance gene (de Ruyter et al., 1996; Kuipers et al., 1998), and/or (ii) to a linkage between nisin and its NisK receptor at the lactococcal surface that is resistant to the washing steps and leads to a persistent nisin induction. To check whether persistent E7 production was due to nisin 


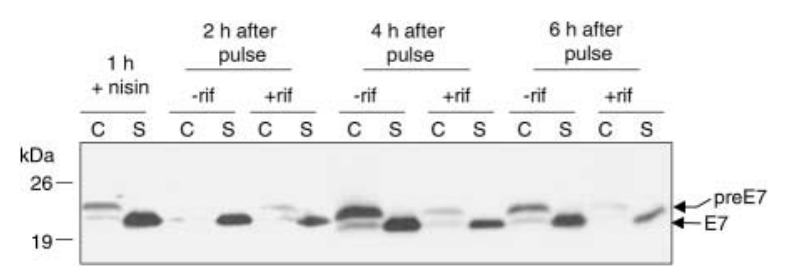

Fig. 4. E7 production after nisin pulse. After $1 \mathrm{~h}$ induction of strain NZ(pSEC : E7) with $10 \mathrm{ng}$ nisin $\mathrm{ml}^{-1}$, the cell pellet was recovered, washed and suspended in fresh GM17 with (+rif) or without rifampicin (-rif). Growth was pursued for 2, 4 and $6 \mathrm{~h}$ and E7 production was analysed by Western blot.

induction even after washing, the induced cultures were incubated with or without rifampicin, an antibiotic that blocks transcription. E7 production was analysed every $2 \mathrm{~h}$ for $6 \mathrm{~h}$. The addition of rifampicin had a dramatic influence on E7 production. The amount of E7 detected $2 \mathrm{~h}$ after the nisin pulse in rifampicin-treated cultures was approximately twofold lower than in cultures without rifampicin. In the presence of rifampicin, E7 levels decreased to trace amounts a few hours after the nisin pulse (Fig. 4). These results suggest that, even after washing, some nisin remained linked to NisK receptors and continued to activate transcription from the PnisA promoter.

These results show that induced $L$. lactis continue to produce and secrete E7 even after sample preparation for intranasal administration. This is totally in accordance with previous results on the in vivo delivery of biologically active molecules by $L$. lactis strains administered intranasally to mice (Bermúdez-Humarán et al., 2003b; Cortes-Perez et al., 2003). As E7 is an extremely labile protein (Reinstein et al., 2000; Bermúdez-Humarán et al., 2002), the lack of significant immune response after immunization with $\mathrm{NZ}$ (pSEC: E7) could be due to rapid degradation of E7 once in vivo or to poor immunogenicity of $\mathrm{E} 7$ protein itself. It is well known that soluble E7 protein is poorly immunogenic and the use of adjuvants is crucial to evoke an immune response (Gérard et al., 2001).

\section{Perspectives on the use of $L$. lactis to treat HPV- related $\mathrm{CxCa}$}

We have previously shown that immunization of mice with an L. lactis strain displaying E7 antigen at its surface evoked a humoral response as corroborated by antibody production (Cortes-Perez et al., 2003). Immune response mediated by antibodies is considered essential in infections. However, to date, the importance of the humoral response in $\mathrm{CxCa}$ remains unclear, even though a potential efficacy has already been suggested (Berumen \& Villegas, 1997). In this work, we show that (i) L. lactis, a food-grade and non-pathogenic bacterium, can efficiently produce E7 antigen in different cellular locations and (ii) recombinant lactococci strains can induce an E7-specific CTL immune response in mice after intranasal administration. These encouraging results repre- sent a step towards the development of a new, safe mucosal vector to treat $\mathrm{HPV}$-related $\mathrm{CxCa}$. Furthermore, as HPV infection is associated with other diseases (i.e. anogenital cancers, papilloma, warts and even some non-melanoma skin cancers) in addition to $\mathrm{CxCa}$, recombinant lactococci engineered to express E7 could ultimately have an impact on other HPV-related diseases.

\section{ACKNOWLEDGEMENTS}

L. G. B.-H. and N.G.C.-P. are the recipients of fellowships from CONACyT, Mexico. L.G.B.-H. is also the recipient of a fellowship from the French Ministry of Research. We thank the members of the 'URLGA' laboratory for helpful suggestions during the realization of this work.

\section{REFERENCES}

Baker, C. C., Phelps, W. C., Lindgren, V., Braun, M. J., Gonda, M. A. \& Howley, P. M. (1987). Structural and transcriptional analysis of human papillomavirus type 16 sequences in cervical carcinoma cell lines. J Virol 61, 962-971.

Bedell, M. A., Jones, K. H. \& Laimins, L. A. (1987). The E6-E7 region of human papillomavirus type 18 is sufficient for transformation of $\mathrm{NIH}$ 3T3 and rat-1 cells. J Virol 61, 3635-3640.

Bermúdez-Humarán, L. G., Langella, P., Miyoshi, A., Gruss, A., TamézGuerra, R., Montes de Oca-Luna, R. \& Le Loir, Y. (2002). Production of human papillomavirus type 16 E7 protein in Lactococcus lactis. Appl Environ Microbiol 68, 917-922.

Bermúdez-Humarán, L. G., Cortes-Perez, N. G., Le Loir, Y., Gruss, A., Rodríguez-Padilla, C., Saucedo-Cardenas, O., Langella, P. \& Montes de Oca-Luna, R. (2003a). Fusion to a carrier protein and a synthetic propeptide enhances E7 HPV-16 production and secretion in Lactococcus lactis. Biotechnol Prog 19, 1101-1104.

Bermúdez-Humarán, L. G., Langella, P., Cortes-Perez, N. G., Gruss, A., Taméz-Guerra, R. S., Oliveira, S. C., Saucedo-Cardenas, O., Montes de Oca-Luna, R. \& Le Loir, Y. (2003b). Intranasal immunization with recombinant Lactococcus lactis secreting murine interleukin-12 enhances antigen-specific Th1 cytokine production. Infect Immun 71, 1887-1896.

Bermúdez-Humarán, L. G., Langella, P., Commissaire, J., Gilbert, S., Le Loir, Y., L'Haridon, R. \& Corthier, G. (2003c). Controlled intra- or extracellular production of staphylococcal nuclease and ovine omega interferon in Lactococcus lactis. FEMS Microbiol Lett 224, 307-313.

Berumen, J. \& Villegas, N. (1997). Vacunas terapéuticas recombinantes contra el cáncer del cuello uterino. Salud Publica Mex 39, 288-297 (in Spanish).

Chatel, J. M., Langella, P., Adel-Patient, K., Commissaire, J., Wal, J. M. \& Corthier, G. (2001). Induction of mucosal immune response after intranasal or oral inoculation of mice with Lactococcus lactis producing bovine beta-lactoglobulin. Clin Diagn Lab Immunol 8, 545-551.

Cortes-Perez, N. G., Bermúdez-Humarán, L. G., Le Loir, Y., RodríguezPadilla, C., Gruss, A., Saucedo-Cardenas, O., Langella, P. \& Montes de Oca-Luna, R. (2003). Mice immunization with recombinant lactococci displaying a surface HPV-16 E7 oncoprotein. FEMS Microbiol Lett 229, $37-42$.

de Ruyter, P. G., Kuipers, O. P. \& de Vos, W. M. (1996). Controlled gene expression systems for Lactococcus lactis with the food-grade inducer nisin. Appl Environ Microbiol 62, 3662-3667.

de Vos, W. M. (1999). Gene expression systems for lactic acid bacteria. Curr Opin Microbiol 2, 289-295. 
Dieye, Y., Usai, S., Clier, F., Gruss, A. \& Piard, J. C. (2001). Design of a protein targeting system for lactic acid bacteria.J Bacteriol 183, 4157-4166.

Drouault, S., Corthier, G., Ehrlich, S. D. \& Renault, P. (1999). Survival, physiology, and lysis of Lactococcus lactis in the digestive tract. Appl Environ Microbiol 65, 4881-4886.

Dyson, N., Howley, P. M., Munger, K. \& Harlow, E. (1989). The human papillomavirus- 16 oncoprotein is able to bind to the retinoblastoma gene product. Science 243, 934-937.

Enouf, V., Langella, P., Commissaire, J., Cohen, J. \& Corthier, G. (2001). Bovine rotavirus nonstructural protein 4 produced by Lactococcus lactis is antigenic and immunogenic. Appl Environ Microbiol 67, $1423-1428$.

Furumoto, H. \& Irahara, M. (2002). Human papillomavirus (HPV) and cervical cancer. J Med Invest 49, 124-133.

Gasson, M. J. (1983). Plasmid complements of Streptococcus lactis NCDO 712 and other lactic streptococci after protoplast-induced curing. J Bacteriol 154, 1-9.

Geoffroy, M. C., Guyard, C., Quatannens, B., Pavan, S., Lange, M. \& Mercenier, A. (2000). Use of green fluorescent protein to tag lactic acid bacterium strains under development as live vaccine vectors. Appl Environ Microbiol 66, 383-391.

Gérard, C. M., Baudson, N., Kraemer, K., Bruck, C., Garcon, N., Paterson, Y., Pan, Z. K. \& Pardoll, D. (2001). Therapeutic potential of protein and adjuvant vaccinations on tumour growth. Vaccine 19, 2583-2589.

Jabbar, I. A., Fernando, G. J., Saunders, N., Aldovini, A., Young, R., Malcolm, K. \& Frazer, I. H. (2000). Immune responses induced by BCG recombinant for human papillomavirus L1 and E7 proteins. Vaccine 18, 2444-2453.

Kok, J., van der Vossen, J. M. \& Venema, G. (1984). Construction of plasmid cloning vectors for lactic streptococci which also replicate in Bacillus subtilis and Escherichia coli. Appl Environ Microbiol 48, 726-731.

Koutsky, L. A., Ault, K. A., Wheeler, C. M., Brown, D. R., Barr, E., Alvarez, F. B., Chiacchierini, L. M. \& Jansen, K. U. (2002). A controlled trial of a human papillomavirus type 16 vaccine. $N$ Engl J Med 347, 1645-1651.

Kuipers, O. P., de Ruyter, P. G., Kleerebezen, M. \& de Vos, W. M. (1998). Quorum sensing-controlled gene expression in lactic acid bacteria. J Biotechnol 64, 15-21.

Langella, P., Le Loir, Y., Ehrlich, S. D. \& Gruss, A. (1993). Efficient plasmid mobilization by pIP501 in Lactococcus lactis subsp. lactis. J Bacteriol 175, 5806-5813.

Londoño, L. P., Chatfield, S., Tindle, R. W., Herd, K., Gao, X. M., Frazer, I. \& Dougan, G. (1996). Immunization of mice using Salmonella typhimurium expressing human papillomavirus type 16 E7 epitopes inserted into hepatitis B virus core antigen. Vaccine 14, 545-552.
Norton, P. M., Brown, H. W., Wells, J. M., Macpherson, A. M., Wilson, P. W. \& Le Page, R. W. (1996). Factors affecting the immunogenicity of tetanus toxin fragment $\mathrm{C}$ expressed in Lactococcus lactis. FEMS Immunol Med Microbiol 14, 167-177.

Parkin, D. M., Pisani, P. \& Ferlay, J. (1999). Global cancer statistics. $C A$ Cancer J Clin 49, 33-64.

Piard, J. C., Jimenez-Diaz, R., Fischetti, V. A., Ehrlich, S. D. \& Gruss, A. (1997). The M6 protein of Streptococcus pyogenes and its potential as a tool to anchor biologically active molecules at the surface of lactic acid bacteria. Adv Exp Med Biol 418, 545-550.

Reinstein, E., Scheffner, M., Oren, M., Ciechanover, A. \& Schwartz, A. (2000). Degradation of the E7 human papillomavirus oncoprotein by the ubiquitin-proteasome system: targeting via ubiquitination of the N-terminal residue. Oncogene 19, 5944-5950.

Reveneau, N., Geoffroy, M. C., Locht, C., Chagnaud, P. \& Mercenier, A. (2002). Comparison of the immune responses induced by local immunizations with recombinant Lactobacillus plantarum producing tetanus toxin fragment $\mathrm{C}$ in different cellular locations. Vaccine 20, $1769-1777$.

Ribeiro, L. A., Azevedo, V., Le Loir, Y., Oliveira, S. C., Dieye, Y., Piard, J. C., Gruss, A. \& Langella, P. (2002). Efficient production and targeting of the Brucella abortus antigen L7/L12 in Lactococcus lactis: a first step towards food-grade live vaccines against brucellosis. Appl Environ Microbiol 68, 910-916.

Robinson, K., Chamberlain, L. M., Schofield, K. M., Wells, J. M. \& Le Page, R. W. (1997). Oral vaccination of mice against tetanus with recombinant Lactococcus lactis. Nat Biotechnol 15, 653-657.

Sambrook, J., Fritsch, E. F. \& Maniatis, T. (1989). Molecular Cloning: a Laboratory Manual, 2nd edn. Cold Spring Harbor, NY: Cold Spring Harbor Laboratory.

Steidler, L., Robinson, K., Chamberlain, L., Schofield, M., Remaut, E., Le Page, R. W. F. \& Wells, J. M. (1998). Mucosal delivery of murine interleukin-2 (IL-2) and IL-6 by recombinant strains of Lactococcus lactis coexpressing antigen and cytokine. Infect Immun 66, 3183-3189.

Tanaka, A., Noda, T., Yajima, H., Hatanaka, M. \& Ito, Y. (1989). Identification of a transforming gene of human papillomavirus type 16. J Virol 63, 1465-1469.

van der Vossen, J. M., van der Lelie, D. \& Venema, G. (1987). Isolation and characterization of Streptococcus cremoris $\mathrm{Wg} 2$-specific promoters. Appl Environ Microbiol 53, 2452-2457.

Xin, K. Q., Hoshino, Y., Toda, Y. \& 9 other authors (2003). Immunogenicity and protective efficacy of orally administered recombinant Lactococcus lactis expressing surface-bound HIV Env. Blood 102, $223-228$. 